\title{
PENOLAKAN HADIS AHAD DALAM TINJAUAN SEJARAH INGKAR SUNNAH
}

\author{
Syahidin \\ Fakultas Ushuluddin, Adab dan Dakwah IAIN Bengkulu \\ Jalan Raden Fatah Pagar Dewa Bengkulu \\ syahidin@gmail.com
}

\begin{abstract}
Disclaimer of Ahad Hads In Review of History of Ingkar Sunnah. The distinction of hadith between ahad and mutawatir has not appeared at the time of the Prophet and his companions. The companions accept the hadith from someone who narrated to them after the status and credibility of the messenger were clear. This distinction has only emerged in the tabi'in period and afterwards. According to Ibn Hazm (d. $456 \mathrm{H}$ ), in fact all Muslims had previously received ahad traditions, namely the hadith narrated by narrators who were "just and reliable." Furthermore, Ibn Hazm said that all groups did so until the Mu'tazilah emerged a century after the hijriyah, then challenged the ijma. This article reveals how history has emerged from the refusal of the traditions of the hadith as a source of Islamic teachings from classical times to modern times.
\end{abstract}

Keywords: Hadis Ahad, Inkar Sunnah, Mu'tazilah.

Abstrak: Hadis Ahad dalam Tinjauan Sejarah Ingkar Sunnah. Pembedaan hadis antara yang ahad dan mutawatir belum muncul pada masa Rasulullah dan para sahabat. Para sahabat menerima hadis dari seseorang yang meriwayatkan kepada mereka setelah jelas status dan kredibilitas penyampainya. Pembedaan tersebut baru muncul pada masa tabi'in dan sesudahnya. Menurut Ibn Hazm (w. $456 \mathrm{H})$, sesungguhnya seluruh kaum muslimin dahulunya menerima hadis ahad, yakni hadis yang diriwayatkan oleh perawi yang 'adil dan dapat dipercaya. Lebih lanjut ibn Hazm menuturkan bahwa semua golongan melakukan itu samapai kemudian muncul Mu'tazilah satu abad sesudah hijriyah, lalu menetang ijma' tersebut. Tulisan ini mencba mengungkap bagaimana sejarah munculnya penolakan terhadap kehujahan hadis ahad sebagai sumber ajaran Islam dari masa klasik hingga masa modern.

Kata Kunci: Hadis Ahad, Inkar Sunnah, Mu'tazilah.

\section{Pendahuluan}

Dalam sejarah keberadaan dan perkembangannya, hadis telah dihadapkan pada beberapa tantangan dan berbagai situasi yang diwarnai aneka ragam perselisihan pendapat di kalangan para ulama. Munculnya kategorisasi hadis menjadi mutawatir dan ahad pada paruh awal abad ketiga hijriah ${ }^{1}$ menjadi titik awal lahirnya perdebatan dan perbedaan pandangan mengenai keabsaan hadis sebagai dasar sumber ajaran Islam khususnya terhadap hadis yang berkategori ahad. Diskursus kategorisasi hadis menjadi mutawatir dan ahad pada akhirnya berdampak terhadap munculnya keraguan bahkan penolakan terhadap otoritas hadis ahad sebagai sumber ajaran Islam setelah setelah Al-Qur'an, yang juga berarti telah meragukan sebagian besar hadis Rasulullah SAW. Hal ini dekarenakan sebagian besar hadis adalah hadis ahad.

Pembedaan hadis antara yang ahad dan mutawatir belum muncul pada masa Rasulullah dan para sahabat. Para sahabat Rasulullah saw. menerima hadis dari seseorang yang meriwayatkan kepada mereka setelah jelas status dan kredibilitas penyampainya. Pembedaan tersebut baru muncul pada masa tabi'in dan sesudahnya. ${ }^{2}$ Menurut Ibn Hazm (w. 456 $\mathrm{H})$, seluruh umat Islam menerima hadis dari satu orang yang terpercaya hingga datangnya para ahli ilmu kalam Mu'tazilah yang mengambil sikap berbeda. ${ }^{3}$ 


\section{Pembahasan}

\section{a. Diskursus Kehujahan Hadis Ahad}

Munculnya istilah hadis ahad dalam khazanah 'Ulum al-Hadith tidak terlepas dari adanya kategorisasi hadis ditinjau dari jumlah transmiternya. Berdasarkan jumlah perawinya, ulama mengklasifikasi hadis menjadi mutawatir dan ahad. Kategorisasi hadis ditinjau dari jumlah transmiternya tersebut tidak hanya memunculkan istilah baru dalam khazanah ilmu hadis, akan tetapi ia juga melahirkan perdebatan dan perbedaan pandangan di kalangan ulama mengenai keabsahan hadis ahad sebagai sumber otoritas Islam kedua setelah Al-Qur'an.

Pada mulanya sebagian besar ulama hadis tidak menggunakan istilah hadis ahad untuk menunjukkan salah satu pembagian hadis ditinjau dari kuantitas perawinya. ${ }^{4}$ Al-Naisaburi (w. $405 \mathrm{H}$ ) misalnya, menggunakan istilah mashhur, gharib dan fard untuk menunjukkan kuantitas perawi hadis.

Istilah pertama yang digunkan alNaisaburi untuk menunjukkan kuantitas hadis adalah mashhur, menurutnya hadis mashhur tidak selalu berarti sahih dan juga tidak selalu terdapat dalam kitab-kitab hadis sahih. Hadis mashhur juga tidak hanya digunakan oleh para ahli hadis, karena ada istlah mashhur menurut ulama usul al-figh maupun mashhur menurut ahli fikih. Kemudian istilah kedua yang digunakan al-Naisaburi untuk menunjukkan kuantitas hadis adalah gharib. Istilah gharib mencakup di dalamnya beberpa bentuk, yaitu hadis gharib yang sahih, gharib al-shuyukh (penyendirian terhadap seorang guru), dan gharib al-matn (penyendirian matan). Sedangkan istilah ketiga untuk menunjukkan kuantitas perawi adalah hadis al-fard. Hadis al-fard ini meliputi beberapa hal, yaitu penyendirian penduduk dalam periwayatan hadis, penyendirian seorang periwayat dari seorang imam di antara para imam, dan hadis yang diriwayatkan penduduk
Madinah tetapi hanya diriwayatkan oleh perawi lain yang berasal dari penduduk Mekah atau sebaliknya. ${ }^{5}$

Ibn al-Salah (w. $643 \mathrm{H}$ ) menggunakan istilah gharib, 'aziz, dan mashhur dalam menunjukkan kuantitas perawi hadis. Istilah gharib adalah digunakan untuk penyendirian perawi dalam meriwayatkan hadis. Sedangkan 'aziz digunakan untuk hadis yang diriwayatkan dua atau tiga orang perawi, dan hadis yang diriwayatkan oleh orang banyak (jama'ah) dinamkan dengan hadis mashhur. Menurutnya hadis mashhur tercakup di dalamnya hadis mutawatir (lawan dari hadis ahad). Istilah mutawatir menurutnya diperkenalkan oleh ahli fikih dan usul fikih, sedangkan ahli hadis tidak menggunakan istilah mutawatir untuk menunjukkan makna khusus terhadap kuantitas perawi hadis. ${ }^{6}$

Hal senada juga dikemukakan oleh Imam al-Nawawi (w. $676 \mathrm{H}$ ), ia tidak menggunakan istilah hadis ahad dalam menunjukkan kuantitas perawi hadis. Hal ini terlihat jelas dalam kitab al-Taqrib-nya yang kemudian disyarah oleh Imam alSuyuti (w. 911 H). Keduanya menggunakan istilah ghari>b untuk penyendirian dalam periwayatan, istilah 'aziz untuk hadis yang diriwayatkan oleh dua atau tiga orang perawi, dan istilah mashhur untuk hadis yang diriwayatkan oleh lebih dari tiga orang perawi. ${ }^{7}$

Penggunaan istilah hadis ahad di kalangan ulama hadis untuk menunjukkan salah satu pembagian hadis ditinjau dari kuantitas perawinya, baru pertama kali digunakan oleh Khatib alBaghdadi (w. $463 \mathrm{H}$ ) yang kemudian diikuti oleh Ibn Hajar al-'Asqalani (w. 852 H). ${ }^{8}$ Khatib al-Baghdadi membagi hadis ditinjau dari segi kuantitas perawinya menjadi dua macam, yaitu hadis mutawatir dan ahad. Kemudian ia mendefinisikan hadis ahad adalah sebagai hadis yang tidak mencukupi sifat-sifat hadis mutawatir dan tidak menghasilkan pengetahuan yang pasti (al-'ilm al-yaqin) 
walapun diriwayatkan oleh banyak orang. ${ }^{9}$ Sedangkan Ibn Hajar al-'Asqalani mendefinisikan hadis ahad adalah hadis selain mutawatir yang tercakup di dalamnya mashhur, 'aziz, dan gharib. ${ }^{10}$

Dengan demikian penggunaan istilah hadis ahad oleh ulama hadis belum muncul di kalangan ulama mutaqaddimin (ulama hadis generasi awal), istilah tersebut baru muncul pada masa mutaakhirin (ulama hadis setelah abad ketiga hijriyah). Adalah Khat $\} \mathrm{i}>\mathrm{b}$ alBaghda>di> (w. $463 \mathrm{H}$ ) disinyalir yang pertamakali menggunakan istilah hadis ahad di kalangan ulama hadis dan kemudian diikuti oleh Ibn Hajar alAsqalani (w. $852 \mathrm{H}$ ).

b. Tingkat Kebenaran Yang Dihasilkan Hadis Ahad

Secara global, sebagaimana yang dituturkan oleh Yusuf al-Qaradawi bahwa para ahli terbagi ke dalam tiga kelompok pendapat mengenai tingkat kebenaran dan kepastian yang dihasilkan oleh hadis ahad. Pertama, secara mutlak hadis ahad tidak menghasilkan ilmu yang pasti benar, baik hadis itu di dukung oleh qarinah (indikasi tertentu yang menguatkan) ataupun tidak. Pendapat kedua, secara mutlak hadis ahad dapat menghasilkan ilmu yang pasti benar walaupun tanpa ada qarinah. Sementara pendapat ketiga menyatakan bahwa hadis ahad dapat menghasilkan ilmu yang pasti benar jika didukung oleh sejumlah qarinah, dalam artian hadis ahad menghasilkan 'ilm alnazari (kebenaran ilmu secara teoritis), yaitu kebenaran ilmu yang bergantung atas hasil penelitian dan pembahasan yang argumentatif. ${ }^{11}$

Dari semua hal di atas, sebetulnya dapat ditarik kesimpulan bahwa sebenarnya tidak ada pendapat yang mengatakan hadis ahad bisa menghasilkan kepastian (al-'ilm al-yaqin), pendapat yang sering diklaim bahwa hadis ahad menghasilkan kepastian (al'ilm) sebetulnya mengatakan bahwa hadis ahad akan mendatangkan kepastian jika memang ada indikasi yang memastikannya, sehingga kalau demikian maka pembahasannya bukanlah hadis ahad itu sendiri, tetapi pembahasannya beralih pada indikasi atau qarinah (indikasi) yang digunakan, sejauhmana bisa menghasilkan kepastian.

c. Sejarah Penolakan Kehujahan Hadis

\section{Ahad}

Jika sebelumnya telah dijelaskan tentang tingkat kebenaran berita atau pengetahuan yang diperoleh dari hadis ahad, maka persoalan selanjutnya adalah apakah hadis ahad yang tingkat kebenarannya masih diperselisihkan antara menghasilkan pengetahuan yang bersifat pasti (qat'i) atau hanya sebatas dugaan (zanni) itu dapat dijadikan hujah dalam masalah-masalah agama dan wajib mengamalkannya atau tidak.

Persoalan ini tidak kunjung selesai, sejak periode klasik sampai sekarang tetap menjadi persoalan yang sering diperdebatkan. Penentuan diterima atau tidaknya hadis tersebut sebagai hujah atau sumber ilmu dan amal sangatlah penting untuk dikaji dan ditelusuri. Terlebih lagi sebagian besar hadis adalah hadis yang berkategori ahad dan sangat sedikit jumlah hadis mencapai tinggkat mutawatir. Logika yang bisa kita tangkap dari itu adalah, bahwa sebagian besar ajaran Islam bersandar kepada hadis ahad. Jika hadis ahad tidak dapat dijadikan hujah, maka konsekuensinya adalah banyak ajaran Islam yang dipahami dan diyakini mayoritas muslim selama ini akan tergusur. ${ }^{12}$

1. Pengingkaran Hadis Ahad Pada Masa Klasik

Pembedaan hadis antara yang ahad dan mutawatir belum muncul pada masa Rasulullah dan para sahabat. Para sahabat menerima hadis dari seseorang yang meriwayatkan kepada mereka setelah jelas status dan kredibilitas penyampainya. Pembedaan tersebut baru muncul pada masa tabi'in dan sesudahnya. ${ }^{13}$ Menurut Ibn Hazm (w. $456 \mathrm{H}$ ), sesungguhnya 
seluruh kaum muslimin dahulunya menerima hadis ahad, yakni hadis yang diriwayatkan oleh perawi yang 'adil dan dapat dipercaya. Lebih lanjut ibn Hazm menuturkan bahwa semua golongan melakukan itu, samapai kemudian muncul Mu'tazilah satu abad sesudah hijriyah, lalu menetang ijma' tersebut. ${ }^{14}$

Kaum Mu'tazilah berpendapat bahwa hadis ahad itu tidak bisa memberikan sebuah ilmu yang pasti dan meyakinkan. Sementara justifikasi hukum berdasarkan logika menurut mereka adalah pasti, sehingga bisa dijadikan acuan dalam hukum syariat. Dengan alasan itu menurut mereka hukum logika harus didahulukan dari hadis ahad secara mutlak, baik dalam persoalan akidah maupun ibadah praktis. Bahkan dalam masalah akidah mereka menolak seluruh hadis ahad secara totalitas, dengan alasan bahwa persoalan akidah harus dibangun melalui sumber yang bersifat absolut dan pasti, bukan berdasarkan sumber yang bernilai seperti hadis ahad. 15

Menurut Mu'tazilah, hadis ahad tidak bisa dikategorikan sebagai Sunnah, kecuali dalam sebuah konteks pengenalan dan tentunya setelah diketahui relevansinya dengan logika. Oleh sebab itu, menurut logika tidak bisa disebutkan misalnya, "Rasulullah bersabda", namun harus disebutkan, "Diriwayatkan dari Nabi". Akibat dari semua itu adalah bahwa kaum Mu'tazilah menolak banyak sekali persoalan akidah yang bersumber dari hadis ahad, seperti tentang siksa kubur, mengimani adanya telaga Nabi saw, adanya al-sirat, al-mizan (timbangan untuk amal perbuatan), shafa'at, dan masalah melihat Allah di akhirat. Mereka juga menolak banyak hukum-hukum syariat yang sah dengan alasan bertentangan dengan logika dan kontradiktif dengan Al-Qur'an, atau berlawanan dengan hadis-hadis lain. Itulah beberapa contoh penyimpangan Mu'tazilah yang diesbutkan oleh Ibn Qutaibah (w. $276 \mathrm{H}$ ) yang dikutif oleh
Abd al-Qahir al-Baghdadi dalam kitabnya al-Farq bayna al-Firaq. ${ }^{16}$

Di antara tokoh Mu'tazilah yang mengingkari dan tidak menerima hadis ahad baik dalam masalah akidah maupun hukum shar'i adalah Abu Hasan alKhayyat\}. Begitu juga Abu Huzail Ali alJubbai sebaigamana dikatakan al-Maziri dan lainnya, disebut sebagai orang yang tidak mau menerima hadis, jika hanya diriwayatkan oleh satu perawi adil. Menurutnya hadis seperti ini baru dapat diterima dengan syarat, apabila hadis tersebut diperkuat oleh hadis yang diriwayatkan oleh rawi adil lainnya, teks hadis tersebut dikuatkan oleh teks hadis lainnya atau teksnya tidak bertentangan dengan teks Al-Qur'an, kemudian hadis tersebut paling tidak diamalkan oleh sebagian sahabat. ${ }^{17}$

Sebagian dari kalangan Mu'tazilah tidak hanya mengikari keberadaan hadis ahad, tetapi juga terhadap hadis mutawatir, seperti yang dilakukan oleh alNazzam yang berpendapat bahwa boleh saja terjadi kebohongan dalam hadis mutawatir sekalipun tidak terbilang jumlah para periwayatnya, karena lain tujuan dan motivasi. Oleh karena itu, ia menolak hadis mutawatir dan ijmak, karena boleh jadi umat berkonsensus dalam mebuat kesalahan. Demikian juga terhadap hadis ahad yang tidak memberi pengertian ilmu secara pasti. ${ }^{18}$ Sementara itu, Abu Huzail berpendapat bahwa kehujahan khabar tentang berita yang non indrawi (seperti tanda-tanda kenabian dan lain-lain) jumlah perawinya tidak boleh kurang dari 20 orang dan di dalamnya terdapat sebagian ahli surga sekalipun tedapat orang kafir dan fasik. Jika di dalamnya tidak terdapat satu atau sebagian ahli surga sekalipun jumlahnya mutawatir dan tidak mungkin sepakat berbohong, tidak dapat dijadikan hujah. Jumlah periwayat yang kurang dari empat orang tidak dapat memebri hukum apaapa, dan jika perwainya 4-20 orang 
periwayat, ada kalanya memberi faedah kepastian (ilmu) dan adakalanya tidak. ${ }^{19}$ Selain Mu'tazilah, kaum Syi'ah Rafidah, manyoritas kelompok Qadariyah dan juga tentang al-Qasani serta ibn Dawud mereka juga disebut-sebut sebagai yang mengkirari kehujahan hadis perorangan (hadis ahad). ${ }^{20}$ Lebih lanjut al-Qasani mengatakan bahwa hadis ahad tidak menghasilkan sesuatu kecuali yang hanya bersifat zann, dan sesuatu yang zann tidak dapat memberikan kepastian kepada kebenaran sedikitpun. ${ }^{21}$

Masalah utama yang membuat mereka menolak hadis ahad adalah karena hadis ahad dari segi wurud-nya hanyalah bersifat zanni al-wurud, dalam arti kebenaran berita tersebut dari Rasulullah saw. tidak dapat diyakini secara pasti sebagaimana hadis mutawatir. Menurut mereka, urusan agama haruslah didasarkan kepada dalil-dalil qat\}' $i$ yang tingkat kebenaranya dapat diyakini dan dipastikan. Oleh karena itu hanya AlQur'an dan hadis mutawatir saja yang dapat dijadikan hujah dalam masalah agama.22

Pengingkaran sebagian kelompok terhadap kehujahan hadis ahad sebagaimana yang diprakarsai oleh sebagian kelompok Mu'tazilah, Rafidah, dan Qadariyah seperti yang telah dijelaskan sebelumnya, sangat erat kaitannya dengan gerakan ingkar sunnah yang muncul pada masa klasik, yakni pada masa imam al-Shafi'i. Imam alShafi'i menyebut adanya kelompok munkir al-Sunnah atau inkar sunnah. Namun demikian al- al-Shafi'i tidak menjelaskan secara eksplisit siapa saja orang yang menolak sunnah itu. Secara garis besar ada tiga kelompok pengingkar sunnah yang berhadapn dengan al-Shafi'i, yaitu; Pertama kelompok yang menolak sunnah secara keselurahan, golongan ini hanaya mengakui Al-Qur'an saja yang dapat dijadikan hujah. Kedua kelompok yang tidak menerima sunnah kecuali yang semakna dengan Al-Qur'an. Ketiga kelompok yang hanya menerima hadis mutawatir saja dan menolak selain mutawatir (menolak hadis ahad).

\section{Pengingkaran Hadis Ahad Pada Masa} Modern

Penolakan terhadap kehujahan hadis ahad tidak hanya terjadi pada masa klasik (era Mu'tazilah). Kalangan modernis juga melancarkan syubhat yang sama, yaitu menolak kehujahan hadis ahad. Kalau pada masa klasik penolakan terhadap hadis ahad dipelopori oleh Mu'tazilah, maka di abad modern ini dipelopori oleh Muhammad Abduh, Mahmud Shaltut, Muhammad Abu Zahrah, Abu Rayyah, Ahmad Amin dan yang lainnya. ${ }^{23}$ Di antara mereka ada yang menolaknya secara mutlak dan ada yang menolak kehujahannya dalam masalah akidah, sebagaimana yang dinyatakan oleh para pendahulu mereka. Ahmad Amin misalnya, Ia berpendapat bahwa hadis ahad, yaitu hadis selain mutawatir tidak memberi faedah ilmu (yakin) menurut mayoritas ulama usul alfigh dan fikih. Sesungguhnya ia boleh diamalkan ketika kuat dugaannya. ${ }^{24}$ Begitu juga dengan Abu Rayyah, menurutnya hadis ahad ditolak dengan alasan pendapat jumhur bahwa ia tidak dapat memberi ilmu secara pasti sekalipun dikeluarkan oleh al-Bukhari dan Muslim, kebenarannya hanya bersifat dugaan. Dalam banyak ayat-ayat al-Quran kita diperintahkan untuk menjauhi zann. ${ }^{25}$ Abu Rayyah dalam menolak sunnah (khususnya hadis ahad) banyak merujuk kepada pendapat Muhammad Abduh dan Rasyid Rid\}a. Sehingga kedua tokoh ini disebut-sebut sebagai pengingkar sunnah. Namun benarkah Muhammad Abduh mengingkari Sunnah? Must\}afa al-'Azami kelihatannya mebenarkan hal itu, dengan cacatan apabila kesimpulan Abu Rayyah dalam kitabnya Adwa 'ala al-Sunnah alMuhammadiyah itu benar. ${ }^{26}$ Begitu juga Mus\}t\}afa al-Siba'i, secara tidak langsung ia menuduh Muahammad Abduh sebagai pengingkar Sunnah dan menilainya 
sebagai orang yang sedikit perbendaharaan hadisnya. Menurut alSiba'i Muhammad Abduh memilik prinsip bahwa senjata yang paling amapuh membela Islam adalah logika dan argumen yang rasional. Berangkat dari prinsip ini Abduh kemudian mempunyai penilaian lain terhadap kedudukan Sunnah. Pendapat Abduh ini akhirnya dijadikan argumen kuat oleh Abu Rayyah dalam mengingkari Sunnah ${ }^{27}$.

Menurut Ali Mustafa Yaqub, sebenarnya keterangan Muhammad Abduh sebagaimna yang dinukil Abu Rayyah itu masih perlu ditinjau kembali. Masalahnya, boleh jadi Abduh ketika mengatakan hal itu didorong oleh semangat yang menggebu-gebu untuk membumikan ajaran Al-Qur'an, sehingga ia sampai berpendapat bahwa sealin AlQur'an tidak ada gunanya sama sekali. Namun bagaimanapun Abduh telah dituduh sebagai pengingkar Sunnah. Lebih lanjut Mustafa Yaqub menuturkan bahwa ada suatu hal yang kongkrit tentang Muhammad Abduh dalam kaitannya dengan hadis, yaitu Abduh menolak hadis ahad untuk dijadikan dalil dalam masalah akidah. ${ }^{28}$

Senada dengan Abduh, Mahmud Shaltut berkali-kali menegaskan bahwa hadis ahad tidak dapat dipakai dalam masalah-masalah akidah, dengan alasan hadis ahad tidak menghasilkan keyakinan. Masalah akidah adalah masalah yang harus diimani dan diyakini, oleh karena itu akidah harus didasarkan kepada keterangan yang pasti yang tidak ada keraguan di dalamnya. Ini berarti riwayat mutawatir saja yang dapat diterima untuk menetapkan masalah akidah, sedangkan hadis ahad tidak dapat dijadikan dasar dalam menetapkan akidah, karena ia tidak dapat memberikan pengertian yang pasti, ia hanya mengasilkan zann semata. ${ }^{29}$ Begitu juga Muhammad al-Ghazali, ia menegaskan bahwa sesungguhnya akidah itu dasarnya adalah keyakinan yang bersih yang tidak ternodai oleh keragu- raguan. Bagaimanpun juga, Islam dibangun di atas dalil-dalil yang akurat dan dalil logika yang kuat. Tidak ada istilah akidah bagi kami yang hanya dibangun di atas dasar hadis ahad dan tebak-tebakan pikiran semata. ${ }^{30}$

Sedangkan ahli hadis dan jumhur ulama berpendapat bahwa hadis ahad yang telah memenuhi syarat kesahihan sebuah hadis, maka wajib mengamalkannya, pengamalan hadis ahad tersebut berlaku untuk seluruh masalah agama baik akidah maupun masalah lainnya. Para sahabat dan orangorang sesudahnya yang terdiri dari para tabi'in dan generasi Salaf umat ini, baik yang mengatakan, bahwa hadis ahad itu menunjukkan ilmu yang yakin maupun yang berpendapat hadis ahad menunjukkan zann, mereka berijma' (sepakat) atas wajibnya mengamalkan hadis ahad, tidak ada yang berselisih dari mereka kecuali sebagian Mu'tazilah dan Rafid\}ah. ${ }^{31}$ Terkait dengan hal ini, Khati $>b$ al-Baghdadi menjelaskan bahwa keharusan mengamalkan hadis ahad itu adalah pendapat seluruh tabi'in dan para fuqaha sesudahnya di seluruh negeri hingga kini. Tidak ada keterangan yang sampai kepada kami tentang adanya salah seorang dari mereka yang menentangnya atau menyalahinya. ${ }^{32}$

Ibn al-Qayyim menuturkan, bahwa hadis-hadis ahad ini sekalipun tidak menunjukkan kepada yakin, namun la menunjukkan kepada z\}ann al-ghalib (dugaan kuat), boleh bagi kita untuk menetapkan asma' dan sifat-sifat Allah dengannya sebagaimana tidak ada larangan menggunakannya untuk menetapkan hukum-hukum yang sifatnya perintah atau larangan. Jika ada yang membedakan, maka pembedaan itu adalah bat\}il berdasarkan ijma' para ulama. Kemudian Ibn al-Qayyim lebih lanjut menjelaskan bahwa para ulama salaf dan ahli hadis senantiasa mengambil hadis-hadis ahad sebagai dasar berargumentasi dalam masalah-masalah 
sifat, takdir, Asma Allah dan hukum. Tidak ada satu pun riwayat yang menyebutkan ada satu orang dari mereka yang membolehkan berargumentasi dan berhujjah dengan hadis-hadis ahad untuk masalah hukum, tapi melarangnya untuk masalah-masalah akidah. ${ }^{33}$

Senada dengan Ibn al-Qayyim, Nasiruddin al-Albani menegaskan, sesungguhnya pendapat yang menyatakan bahwa hadis-hadis ahad itu tidak bisa dijadikan hujah dalam akidah adalah pendapat bid'ah, tidak ada dasarnya dalam syari' at Islam yang penuh dengan kebajikan. Itu adalah pendapat aneh menurut petunjuk Al-Qur'an dan bimbingan Sunnah bahkan belum dikenal oleh para al-salaf al-salih\}. Pendapat itu hanya dilontarkan oleh segolongan ulama kalam dan sebagian ulama us\}u>l yang kemudian mempengaruhi pemikiran sebagian ulama kontemporer. Lalu pendapat itu diambil begitu saja oleh kaum modernis dengan pasrah, tanpa penyangkalan atau argumetasi yang jelas. Kemudian lebih lanjut al-Albani menuturkan, kalau pendapat itu diambil, berarti ada ratusan hadis sahih yang harus ditolak karena berkaitan dengan akidah. ${ }^{34}$ Apa yang dikemukan oleh Muhammad Nas\}iruddin al-Albani, menurut penulis sangatlah beralasan, karena sebagian besar hadis adalah hadis yang berkategori ahad dan sangat sedikit jumlah hadis yang mencapai tingkat mutawatir. Logika yang bisa ditangkap dari itu adalah, bahwa sebagian besar ajaran Islam baik itu akidah ataupun masalah lainnya bersandar kepada hadis ahad. Jika hadis ahad tidak dapat dijadikan hujah, maka konsekuensinya adalah banyak ajaran Islam yang dipahami dan diyakini mayoritas muslim selama ini akan tergusur. ${ }^{35}$

\section{Kesimpulan}

Berdasarkan apa yang sudah dipaparkan di atas dapat ditarik kesimpulan bahwa Pembedaan hadis antara yang ahad dan mutawatir belum muncul pada masa Rasulullah dan para sahabat. Para sahabat menerima hadis dari seseorang yang meriwayatkan kepada mereka setelah jelas status dan kredibilitas penyampainya. Pembedaan tersebut baru muncul pada masa tabi'in dan sesudahnya. Menurut Ibn Hazm (w. 456 $\mathrm{H})$, sesungguhnya seluruh kaum muslimin dahulunya menerima hadis ahad, yakni hadis yang diriwayatkan oleh perawi yang 'adil dan dapat dipercaya. Lebih lanjut ibn Hazm menuturkan bahwa semua golongan melakukan itu, samapai kemudian muncul Mu'tazilah satu abad sesudah hijriyah, lalu menetang ijma' tersebut.

Kaum Mu'tazilah berpendapat bahwa hadis ahad itu tidak bisa memberikan sebuah ilmu yang pasti dan meyakinkan. Sementara justifikasi hukum berdasarkan logika menurut mereka adalah pasti, sehingga bisa dijadikan acuan dalam hukum syariat. Dengan alasan itu menurut mereka hukum logika harus didahulukan dari hadis ahad secara mutlak, baik dalam persoalan akidah maupun ibadah praktis. Bahkan dalam masalah akidah mereka menolak seluruh hadis ahad secara totalitas, dengan alasan bahwa persoalan akidah harus dibangun melalui sumber yang bersifat absolut dan pasti, bukan berdasarkan sumber yang bernilai seperti hadis ahad.

Penolakan terhadap kehujahan hadis ahad tidak hanya terjadi pada masa klasik (era Mu'tazilah). Kalangan modernis juga melancarkan syubhat yang sama, yaitu menolak kehujahan hadis ahad. Kalau pada masa klasik penolakan terhadap hadis ahad dipelopori oleh Mu'tazilah, maka di abad modern ini dipelopori oleh Muhammad Abduh, Mahmud Shaltut, Muhammad Abu Zahrah, Abu Rayyah, Ahmad Amin dan yang lainnya. 


\section{Referensi}

${ }^{1}$ Pembagian hadis mutawatir dan ahad tidaklah dimulai oleh kalangan ahli hadis generasi awal (tidak ada asalnya dari kalangan A shab al-Hadith). Namun, pembagian itu dimulai oleh kalangan ahli usłall dan ahli kalam. Pembagian tersebut pertama kali dilakukan oleh Abdurrahman bin Kaisan Al-A sạm yang kemudian diikuti oleh muridnya yang bernama Ibrahim bin Isma'il bin Ibrahim. Ibrahim bin Isma'il ini adalah seorang Jahmi (penganut paham Jahmiyyah paham sesat yang telah dikafirkan para ulama). Maka, kita tidak akan menemukan pembagian ahad dan mutawatir ini di kalangan ulama ahli hadis terdahulu. Kalaupun misal sebagian ulama menyebutkan ahad dan mutawatir, itu bukanlah seperti yang dimasud oleh kalangan ahli usul. Namun hal itu semata-mata hanya dilihat dari jumlah perawi saja. Hal itu tercermin sebagaimana dalam kitab al-Risalah karangan Imam al-Shafi'i. Beliau menyebutkan khabar wahid atau khabar ahad, namun maksud beliau semata-mata hanyalah penekanan pada jumlah perawi saja yang menyampaikan hadis yaitu satu orang. 'A skun bin M uhammad Nasiłi al-U rduni, $\mathrm{H}$ фdiț Ahł bayna Ishkaliyah al-Istilah\} wa Salbiyah alM admun.

http://www .ahlal hdeeth.com/vb/showthread.php?t=2991 93. Diakses pada 09 Juni 2013. Bandingkan dengan: Huseyin Hasnu, "Notes on the Term Mutawatir and its Reception in Hadith Critisim." dalam Journal Islamic Law and Society 16 (2009): 383-408.

${ }^{2} \mathrm{~L}$ ihat 'A bd al-M uhdi 'A bd al-Qadir, Daf' $u$ alShubuhat 'An al-Hadith al-N abawi (K airo: M aktabah alI man, 2010), 84.

${ }^{3}$ Salim 'Ali al-B ahanasawi, al-Sunnah al-M uftara 'A laiha (K uwait: Dar al-Buhith al-'IImiyah, 1992), 140.

${ }^{4}$.Sebenarnya pembagian hådis mutawatir dan ahad tidaklah dimulai oleh kalangan ahli hadis di kalangan awal (tidak ada asalnya dari kalangan A shabu al-Hadith). Namun, pembagian itu dimulai oleh kalangan ahli usiłl dan ahli kalam. Pembagian tersebut pertama kali dilakukan oleh Abdurrahman bin Kaisan Al-A S\$m yang kemudian diikuti oleh muridnya yang bernama Ibrahim bin Isma'il bin Ibrahim. Ibrahim bin Isma'il ini adalah seorang Jahmi. M aka, kita tidak akan ditemukan pembagian ahad dan mutawatir ini di kalangan ulama ahli hadis terdahulu. Kalaupun misal sebagian ulama menyebutkan ahad dan mutawatir, itu bukanlah seperti yang dimasud oleh kalangan ahli usul. Namun hal itu semata-mata hanya dilihat dari jumlah perawi saja. Hal itu tercermin sebagaimana dalam kitab al-Risalah karangan Imam al-Shafi'i. Beliau menyebutkan khabar wahid atau khabar ahad, namun maksud beliau semata-mata hanyalah penekanan pada jumlah perawi saja yang menyampaikan hadis yaitu satu orang. Lihat 'A bd al-M uhdi 'Abd al-Qadir, Daf'u alShubhat 'A $n$ al-Hodith al-Nabawi (Cairo: Maktabah alIman, 2010), 84.

${ }^{5} \mathrm{M}$ uhłmmad ibn Abdullah al-H售 alNaisaburi, Ma'rifah 'Ulum al-Hadith (M adinah: alM aktabah al-'Ilmiyyah, 1977), 93-96.

${ }^{6} \mathrm{Abu}$ 'U mar 'Usman ibn 'A bdurrahinan ibn Salah, Muqaddimah ibn Salah\} fi>'Ulum al-H dith (B airut: Da»al-Kutub al-'Ilmiyyah, 2003), 16.
7Jalaluddin al-Suyut\}, Tadrib al-Rawi fi Sharh\} Taqrib al-Nawawi (Riyad: Maktabah al-K authar, 1997, juz. 2), 632-636.

${ }^{8} \mathrm{http}: / /$ www.ahlalhdeeth.com/vb/showthread.php $? \mathrm{t}=299193 \mathrm{Di}$ akses pada 14 Februari 2013.

${ }^{9} \mathrm{~A}$ bu Bakar A hinad bin 'A li bin Thabit al-K hatibo al-Baghdadi, al-K ifayah fi 'Ilm al-Riwayah (Bairut: Dar al-Kutub al-IImiyah, 1988), 16-17.

${ }^{10}$ Ibnu Hajar al-A sqalani, Nuzhah al-Nazłr fi Taudih Nukhbat Ahl al-Fikr fi Musfollah\}A hl al-A thar (Damshiq: M atßa' ah al-S ababa\} cetakan ke 3, 2000), 51.

${ }^{11} Y$ usuf al-Q aradawi, al-M arja'iyah al-'Ulyafi alIslam Li AI-Q ur' an wa al-Sunnah (Bairut: M uassasah alRisalah, 1996), 117-118.

12 Lihat Ali Mustafa Yaqub, Kritik Hadis (J akarta: Pustaka Pirdaus, cet. K e-5, 2008), 133.

${ }^{13} \mathrm{~L}$ ihat 'A bd al-M uhdi $>A$ bd al-Qadir, Daf' $u$ alShubhat'A $n$ al-Hadith al-Nabawi (Cairo: Maktabah alIman, 2010), 84.

${ }^{14}$ Salim 'Ali al-Bahanasawi> al-Sunnah alMuftara' 'Alaiha (K uwait: Dar al-Buhiłth al-'Ilmiyah, 1992), 140

${ }^{15} \mathrm{M}$ uhămmad Hamid al-Nasir, al-'A sraniyyun bayn Maza'im al-Tajdid wa Mayadin al-Taghrib, terj. A bu U mar B ashir, (J akarta: D arul Haq, 2004), 22.

${ }^{16}$ al-Nakis, al-'A staniyyun bayn Maza'im alTajdid, 23. Litah juga $A$ bd al-Q ahir al-B aghdadi, al-Farq bayn al-Firaq, (Bairut: Maktabah al-'A skjyyyah, 1995), 127-142.

${ }^{17} \mathrm{~A}$ bu Lubabah Husain, Mauqif al-Mu'tazilah min al-Sunnah al-Nabawiyah, terj. Usman Sy'roni (J akarta: Pustaka Firdaus, 2003), 77-78.

${ }^{18} \mathrm{~A}$ bdul $\mathrm{M}$ ajid K hon, Pemikiran M odern dalam Sunnah; Pendekatan IImu Hadis (Jakarta: Prenada M edia Grop, 2011), 51. Lihat juga A bd al-Q ahir al-Baghdadi, al-Farq bayn al-Firaq, (Bairut: Maktabah al-'A słijyyah, 1995), 158-159.

51

${ }^{19} \mathrm{M}$ ajid K hon, Pemikiran M odern dalam Sunnah,

${ }^{20} \mathrm{M}$ usfffla al-Siba'i, al-Sunnah wa M akanatuha fi al-T ashri'i al-Islami (t.tp: Dar al-W araq, 2000), 142.

${ }^{21} \mathrm{M}$ uhammad bin Ali al-Shaukani, Irshad al-

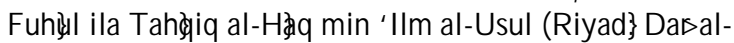
F adistah, 2000), 39.

${ }^{22}$ Rif'at Fauzi Abd al-Mutalib, Tauthiq alSunnah fi Qarn al-Thani al-Hijr; A sasuhu wa Ijtijahatuhu (K airo: M aktabah al-K hanaji, 1983), 90.

23 Ali Mustga Yaqub, Kritik Hadis (Pustaka Firdaus, cetakan ke-5, 2008), 46-47.

${ }^{24} \mathrm{~A}$ hmad A min, Fajr al-Islam cet. Ke-2 (K airo:

M aktabah al-N ahdgh al-M isłijyah, 1975), 218.

${ }^{25} \mathrm{~A}$ bu Rayyah, A dwa 'ala al-Sunnah (Kairo: Das al-M a'arif. tth), 250.

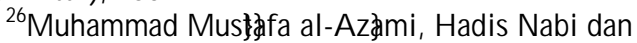
Sejarah K odifikasinya, terj. A li M ustafa Y uqub (J akarta: Pustaka Pirdaus, cet. 3, 2006), 46.

${ }^{27} \mathrm{M}$ usfffla al-Siba'i, al-Sunnah wa $\mathrm{M}$ akanatuha fi Tashri'i al-Islami (t.tp: Dar al-Waraq, 2000), 122.

${ }^{28} \mathrm{Ali}$ M ustgfa Yaqub, Kritik Hadis (Pustaka Firdaus, cetakan ke-5, 2008), 48.

${ }^{29} \mathrm{M}$ ahmud Shaltut, al-Islam 'A qidah wa Shari'ah (Kairo: Dar al-Shuruq, 2001), 58-59. 
${ }^{30}$ M uhammad al-Ghazali, Al-Sunnah alNabawiyah baina $\mathrm{Ahl}$ al-Figh wa A hl al-Hadith (Kairo: Dar al-Shuruq, 2005), 66.

${ }^{31} \mathrm{M}$ uhłmmad Hamid al-Nasir, al-'A sraniyyun bayn Maza'im al-Tajdid wa Mayadin al-Taghrib, terj. A bu U mar Bashir, (J akarta: Darul Haq, 2004), 223.

${ }^{32} \mathrm{Abu}$ Bakar Ahphad bin 'Ali bin Thabit alKhatils al-Baghdadi, al-K ifaæah fi 'Ilm al-Riwaæah (B airut: Dar al-Kutub al-IImiyah, 1988), 72.

${ }^{33}$ Ibn Qayyim al-Jauziyah, M ukhtasłr al-Sawa'iq al-M ursalah 'ala al-Jahmiyah al-M u'attglah (Riyad\}? M aktabah A dwa al-Salaf, juz. 2, 2004), 412.

${ }^{34} \mathrm{M}$ uhammad Nasiruddin al-A lbasi, al-Hadith $\mathrm{H}$ k্jjah bi Nafsihi fi al-'Aqaid wa al-Ahkam (Kuwait: Dar al-Salafiyyah, 1987), 54-55.

${ }^{35} \mathrm{~B}$ andingkan dengan A li M ustafa $\mathrm{Y}$ aqub, Kritik Hadis (J akarta: Pustaka Pirdaus, cet. K e-5, 2008), 133. 